\title{
Irinotecan (CPT-11) Canonical Anti-Cancer Drug Can also Modulate Antiviral and Pro-Inflammatory Responses of Primary Human Synovial Fibroblasts
}

\author{
Anthony Dobi ${ }^{1, *}$, Philippe Gasque ${ }^{1,2}$, Pascale Guiraud ${ }^{1}$ and Jimmy Selambarom ${ }^{1}$ (D) \\ 1 Unité de Recherche en Pharmaco-Immunologie (UR-EPI), Université et CHU de La Réunion \\ (Site Félix Guyon), 97400 Saint-Denis, France; philippe.gasque@univ-reunion.fr (P.G.); \\ pascale.guiraud@univ-reunion.fr (P.G.); jimmy.selambarom@univ-reunion.fr (J.S.) \\ 2 Laboratoire d'Immunologie Clinique et Expérimentale de la Zone Océan Indien (LICE-OI), Pôle de Biologie, \\ CHU de La Réunion (Site Félix Guyon), 97400 Saint-Denis, France \\ * Correspondence: anthony.dobi@univ-reunion.fr; Tel.: +262-0-692-1797-04
}

check for updates

Citation: Dobi, A.; Gasque, P.; Guiraud, P.; Selambarom, J. Irinotecan (CPT-11) Canonical Anti-Cancer Drug Can also Modulate Antiviral and Pro-Inflammatory Responses of Primary Human Synovial Fibroblasts. Cells 2021, 10, 1431. https://doi.org/ 10.3390/cells10061431

Academic Editors: Sylvain G Bourgoin and Paola Cappello

Received: 25 February 2021

Accepted: 24 May 2021

Published: 8 June 2021

Publisher's Note: MDPI stays neutral with regard to jurisdictional claims in published maps and institutional affiliations.

Copyright: (c) 2021 by the authors. Licensee MDPI, Basel, Switzerland. This article is an open access article distributed under the terms and conditions of the Creative Commons Attribution (CC BY) license (https:// creativecommons.org/licenses/by/ $4.0 /)$.

\begin{abstract}
Alphaviruses are a group of arboviruses that generate chronic inflammatory rheumatisms in humans. Currently, no approved vaccines or antiviral therapies are available to prevent or treat alphavirus-induced diseases. The aim of this study was to evaluate the repositioning of the anticancer molecule irinotecan as a potential modulator of the antiviral and inflammatory responses of primary human synovial fibroblasts (HSF), the main stromal cells of the joint synovium. HSF were exposed to O'nyong-nyong virus (ONNV) and polyinosinic-polycytidylic acid (PIC) to mimic, respectively, acute and chronic infectious settings. The cytokine IL-1 $\beta$ was used as a major proinflammatory cytokine to stimulate HSF. Quantitative RT-PCR analysis revealed that irinotecan at $15 \mu \mathrm{M}$ was able to amplify the antiviral response (i.e., interferon-stimulated gene expression) of HSF exposed to PIC and reduce the expression of pro-inflammatory genes (CXCL8, IL-6 and COX-2) upon IL-1 $\beta$ treatment. These results were associated with the regulation of the expression of several genes, including those encoding for STAT1, STAT2, p53 and NF-kB. Irinotecan did not modulate these responses in both untreated cells and cells stimulated with ONNV. This suggests that this drug could be therapeutically useful for the treatment of chronic and severe (rather than acute) arthritis due to viruses.
\end{abstract}

Keywords: irinotecan; arthritis; alphavirus infection; human synovial fibroblasts; antiviral response; pro-inflammatory response

\section{Introduction}

Infectious diseases are a well-recognized cause of acute arthralgia and arthritis. There is currently a lack of accurate data on the incidence and prevalence of viral arthritis worldwide. Studies performed on patients affected by acute arthritis have suggested a viral origin in about $1 \%$ of cases [1]. Among arthritogenic viruses, the genus Alphavirus, a member of the family Togaviridae, has been reported to generate epidemics in most parts of the world, sometimes with a severe impact on human health [2]. Alphaviruses are enveloped positive-sense RNA viruses transmitted by bites of infected mosquitoes and are importantly involved in inflammatory diseases, including arthritis and encephalitis [3]. "Old World" alphaviruses, of which Chikungunya virus (CHIKV) is the most well-known, are related to rheumatic diseases in humans that can turn into a chronic form. Clinical manifestations of chronic arthralgia and arthritis after alphaviral infection range from a restriction of movements with persistence of swelling and pain located in joints to a debilitating illness [4,5].

The production of type I interferon (IFN- $\alpha$ and IFN- $\beta$ ) and, subsequently, IFNstimulated genes (ISGs) by virus-infected cells is a hallmark of the innate immunity, allowing one to control alphaviral replication. However, inflammatory mediators, such 
as CCL2 and CXCL8, play a central role in disease progression towards a chronic phase, particularly in the process of immune cells' recruitment in the synovial fluid of inflamed joints [6,7]. Although macrophages are thought to be key effectors of the pathology through the release of pro-inflammatory cytokines, chemokines and matrix metalloproteinases, synovial fibroblasts are also important contributors of inflammation and joint damage. For instance, it has been demonstrated that human synovial fibroblasts (HSF) infected by CHIKV secrete mediators (RANKL, IL-6, IL-8 and CCL2) that are responsible for the recruitment of phagocytes and their differentiation into osteoclast-like cells involved in bone erosion [8]. In this context, the inhibition of virus replication, as well as pro-inflammatory processes related to synovial fibroblasts are of therapeutic interest.

Alkaloids, a class of nitrogen-containing organic compounds, are secondary metabolites of plants that are recognized to inhibit the replication of several viruses, particularly RNA viruses, including CHIKV [9], influenza virus [10], dengue virus [11] and porcine epidemic diarrhea virus [12]. Among alkaloids, water-insoluble camptothecin (CPT) and its derivatives, described as inhibitors of DNA topoisomerase I and traditionally used as anti-cancer drugs, have been shown to affect the replication of many viruses, including DNA viruses [13], influenza virus [14] and HIV-1 [15]. In addition, a genome-wide transcriptional analysis of human fibroblasts treated with CPT showed that the molecule was able to regulate the expression of a wide range of genes, including proto-oncogenes, p53 target genes, pro- and anti-apoptotic genes [16].

Hence, in the present study, our aim was to develop an in vitro model to ascertain whether or not CPT may modulate the antiviral and pro-inflammatory gene expression of HSF in the context of alphaviral infection and viral persistence in the joints of patients affected by chronic inflammatory rheumatisms. We used the camptothecin-derived soluble drug irinotecan (CPT-11) that was approved for the treatment of cancer in 1994 and that remains currently a major anti-cancer drug worldwide [17]. Primary HSF were exposed to O'nyong-nyong virus (ONNV), a virus closely related to $\mathrm{CHIKV}$, with which it shares 89\% genetic sequence homology [18]. Polyinosinic-polycytidylic acid (PIC), a synthetic analogue of viral double-stranded RNA, and the pro-inflammatory cytokine IL-1 $\beta$ were also applied to cells. Gene expression analysis revealed that CPT-11 can modulate both the antiviral and pro-inflammatory responses of HSF.

\section{Materials and Methods}

\subsection{Cells and Reagents}

Primary HSF were obtained from ScienCell Research Laboratories (ScienCell, 4700; Clinisciences, Carlsbad, CA, USA). Cells were cultured in Modified Eagle's Medium (MEM eagle, PAN Biotech P0408500, Aidenbach, Germany) supplemented with 10\% heat-inactivated fetal bovine serum (FBS, PAN Biotech, 3302 P290907, Aidenbach, Germany), 2 mM L-glutamine (Biochrom AG, K0282, Berlin, Germany), $0.1 \mathrm{mg} / \mathrm{mL}$ penicillinstreptomycin (PAN Biotech, P0607100), 1 mM sodium pyruvate (PAN Biotech, P0443100) and $0.5 \mu \mathrm{g} / \mathrm{mL}$ amphotericin B (PAN Biotech, P0601001).

ONNV was provided by the CNR (Centre national de référence) Arbovirus of Marseille (France). Polyinosinic-polycytidylic acid (PIC) was purchased from Amersham Biosciences, Little Chalfont, UK (catalog number: 27-4732-01) and recombinant human IL-1 $\beta$ and TNF- $\alpha$ from Peprotech, Rocky Hill, CT, USA (catalog number: 200-01B and 300-01A, respectively). Irinotecan hydrochloride trihydrate was obtained from "medac Gesellschaft für klinische Spezialpräparate $\mathrm{mbH}^{\prime \prime}$ (Wedel, Germany).

\subsection{Cell Culture and Treatments}

HSF were cultured in 6-well plates or 96-well plates. Cells were maintained at $37^{\circ} \mathrm{C}$ in a humidified atmosphere containing $5 \% \mathrm{CO}_{2}$. The medium was replaced twice a week and cells were treated at about $80 \%$ confluence. All treatments were performed for 6 and $24 \mathrm{~h}$. HSF were infected with ONNV at a multiplicity of infection (MOI) of 0.1 and 1 and under biosafety level 2 practices. After the infection time, tissue culture plates were inactivated 
with ultraviolet light for $5 \mathrm{~min}$. PIC was used at $1 \mu \mathrm{g} / \mathrm{mL}$, IL- $1 \beta$ at $10 \mathrm{ng} / \mathrm{mL}$ and TNF- $\alpha$ at $50 \mathrm{ng} / \mathrm{mL}$. Cells were co-treated (or not) with CPT- 11 at $15 \mu \mathrm{M}$.

\subsection{MTT Assay}

MTT (3-(4,5-Dimethylthiazol-2-yl)-2,5-Diphenyltetrazolium Bromide) assay was performed to investigate the influence of ONNV, PIC, IL-1 $\beta$ and CPT-11 on HSF viability. After $24 \mathrm{~h}$ of treatment in 96-well plate, MTT was added to each well at a final concentration of $0.5 \mathrm{mg} / \mathrm{mL}$, followed by $3 \mathrm{~h}$ of incubation at $37^{\circ} \mathrm{C}$. After discarding the medium, dimethylsulfoxide was added to each well $(100 \mu \mathrm{L})$ and the plate was shaken for $15 \mathrm{~min}$ to solubilize formazan crystals. Absorbance was read at $570 \mathrm{~nm}$. Results were expressed as the percentage of control (untreated cells).

\subsection{Cytotoxicity Assay (LDH Assay)}

Cytotoxicity was assessed with the CytoTox $96{ }^{\circledR}$ Non-Radioactive Cytotoxicity Assay (PROMEGA, Madison, USA, catalog number: G1780), which is a colorimetric assay allowing for the detection of lactate dehydrogenase (LDH) released from damaged cells, in supernatants. Experiments were carried out in sextuplicate in 96-well plates. The percentage of cellular injury was calculated using the following formula: percent cytotoxicity $=100 \times$ experimental LDH release/maximum LDH release. Maximum LDH release was determined after $24 \mathrm{~h}$ of cell treatment with $0.5 \%$ triton.

\subsection{Reverse Transcription Quantitative Real-Time Polymerase Chain Reaction (RT-qPCR)}

Total RNA extraction was performed using the RNeasy Plus Mini Kit (Qiagen, Hilden, Germany, catalog number: 74136). HSF were cultured and treated in 6-well plates. After treatments, supernatants were collected and stored at $-80^{\circ} \mathrm{C}$. Cells were washed with $1 \mathrm{X}$ PBS and lysed with $350 \mu \mathrm{L}$ RLT lysis buffer. Cell lysates were stored at $-80^{\circ} \mathrm{C}$ until RNA extraction, according to the manufacturer's instructions. Total RNA was eluted in a final volume of $50 \mu \mathrm{L}$ RNase free water and used for RT-qPCR experiments, otherwise stored at $-80^{\circ} \mathrm{C}$. RT-qPCR was carried out in triplicate using the One-Step TB Green PrimeScript ${ }^{\mathrm{TM}}$ RT-PCR Kit (Takara Bio Inc., Kusatsu, Japan, catalog number: RR066A) in a final volume of $5 \mu \mathrm{L}$ containing $1 \mu \mathrm{L}$ of total RNA (or RNase free water as a blank non-template control), $2.7 \mu \mathrm{L}$ of enzyme mix and $1.3 \mu \mathrm{L}$ of primers mix at a final concentration of $250 \mathrm{nM}$. The specific primers used are listed in Table 1. The RT-qPCR program was executed with the QuantStudio 3 Real-Time PCR System with the following steps: a reverse transcription at $42{ }^{\circ} \mathrm{C}$ for $5 \mathrm{~min}$ and 40 cycles comprising a denaturation step at $95^{\circ} \mathrm{C}$ for $5 \mathrm{~s}$, an annealing step at $58{ }^{\circ} \mathrm{C}$ for $15 \mathrm{~s}$ and an extension step at $72{ }^{\circ} \mathrm{C}$ for $15 \mathrm{~s}$. Fluorescence data were collected at $520 \mathrm{~nm}$. PCR reactions were validated by analyzing the melting curve of each pair of primers with the QuantStudio Design and Analysis Software v1.5.1 (ThermoFisher Scientific, Waltham, MA, USA). Relative gene expression was calculated using GAPDH as a housekeeping gene and the fold change versus control (set to 1) was calculated for each gene. Of note, when control values were equal to zero (in the case of viral genes' amplification in uninfected cells), the $2^{-\Delta \mathrm{Ct}}$ values were reported for other conditions [19]. 
Table 1. List of primers used for RT-qPCR.

\begin{tabular}{|c|c|}
\hline Gene Name & Sequence $\left(5^{\prime} \rightarrow 3^{\prime}\right)$ \\
\hline GAPDH_F (Forward) & TGTTCGTCATGGGTGTGAAC \\
\hline GAPDH_R (Reverse) & GCATGGACTGTGGTCATGAG \\
\hline E1_F & CACCGTCCCCGTACGTAAAA \\
\hline E1_R & GGCTCTGTAGGCTGATGCAA \\
\hline nsP2_F & GCGGAGCAGGTAAAAACGTG \\
\hline nsP2_R & TAGAACACGCCCGTCGTATG \\
\hline ISG15_F & AGATCACCCAGAAGATCGGC \\
\hline ISG15_R & GAGGTTCGTCGCATTTGTCC \\
\hline IFN- $\beta \_F$ & GTTCGTGTTGTCAACATGACCAA \\
\hline IFN- $\beta \_R$ & TCAATTGCCACAGGAGCTTCT \\
\hline MDA5_F & CTGTTTACATTGCCAAGGATC \\
\hline MDA5_R & ACACCAGCATCTTCTCCATTT \\
\hline STAT1_F & TGGTGAAATTGCAAGAGCTG \\
\hline STAT1_R & AGAGGTCGTCTCGAGGTCAA \\
\hline p53_F & GAAGAGAATCTCCGCAAGAAAGG \\
\hline p53_R & TCCATCCAGTGGTTTCTTCTTTG \\
\hline ISG54_F & CTGGTCACCTGGGGAAACTA \\
\hline ISG54_R & GAGCCTTCTCAAAGCACACC \\
\hline OAS1_F & CATGCAAATCAACCATGCCA \\
\hline OAS1_R & ACAACCAGGTCAGCGTCAGATC \\
\hline PKR_F & GTGATGCAGCTCACAATGCT \\
\hline PKR_R & GGCACTGTAAAATGGGTGCT \\
\hline CXCL8_F & CAGAGACAGCAGAGCACACA \\
\hline CXCL8_R & GGCAAAACTGCACCTTCACA \\
\hline IL-6_F & TACAGGGAGAGGGAGCGATAA \\
\hline IL-6_R & TGGACCGAAGGCGCTTGT \\
\hline COX-2_F & TGGCTACAAAAGCTGGGAAG \\
\hline COX-2_R & GGGGATCAGGGATGAACTTT \\
\hline NFKB1_F & CCGGCCCGCCTGAATCATTCTC \\
\hline NFKB1_R & CAGGTGGCGACCGTGATACCT \\
\hline
\end{tabular}

\subsection{Enzyme-Linked Immunosorbent Assay (ELISA)}

Cytokine and chemokine concentrations in supernatants of HSF were measured using commercially available ELISA kits for CXCL8 (Peprotech, Rocky Hill, CT, USA, catalog number: 900-T18) and IL-6 (eBioscience, ThermoFisher Scientific, Waltham, MA, USA, catalog number: 88-7066-88), according to the manufacturer's instructions.

\subsection{Western Blot Analysis}

Cultured HSF were washed with PBS and cells were scraped off the plate. Protein extraction was performed using 1\% Triton X-100 lysis buffer (150 mM sodium chloride, $50 \mathrm{mM}$ Tris $\mathrm{pH}$ 7.5) supplemented with a cocktail of protease inhibitors (ThermoFischer Scientific, Waltham, MA, USA, catalog number: A32961). Equal amounts of cell lysate protein $(10 \mu \mathrm{g})$, determined by Bradford assay, were mixed with 1X Laemmli buffer and then loaded on NuPAGE 4-12\% Bis-Tris Gel (Invitrogen, ThermoFisher Scientific, Waltham, MA, USA, catalog number: NP0336BOX) for SDS-PAGE electrophoresis (50 mA per gel, for one hour and thirty minutes). Separated proteins were transferred to a $0.45 \mu \mathrm{m}$ nitrocellulose membrane (Amersham Biosciences, Little Chalfont, UK, catalog number: RPN303E) at $50 \mathrm{~mA}$, for one hour and fifteen minutes. The membrane was then blocked with $5 \%$ non-fat dry milk containing $0.1 \%$ Tween 20 and incubated overnight at $4{ }^{\circ} \mathrm{C}$ with primary antibodies against COX-2 (Rabbit anti-COX-2, Cell Signaling Technology, Danvers, MA, USA, catalog number: 4842) or $\beta$-actin (Mouse anti- $\beta$-Actin antibody, Sigma-Aldrich, Saint-Louis, MO, USA, catalog number: A1978), at a 1:1000 dilution. The membrane was washed three times with PBS containing 0.1\% Tween 20 and incubated with the appropriate horseradish peroxidase-conjugated secondary antibodies (Goat anti-Rabbit or Goat anti-Mouse, catalog numbers: 172-1019 and 172-1011, respectively) for one hour, at room temperature. After 
washing, revelation was performed using enhanced chemiluminescence reagent (Amersham, catalog number: RPN2232) and acquired with a Fusion Fx Spectra imager (Vilber, Marne-la-Vallée, France). Spot quantification from Western blot images was performed using the Fusion Fx Spectra software.

\subsection{Statistical Analysis}

Data are expressed as mean \pm standard error (SEM) from at least four independent experiments. Statistical analysis was performed using one-way ANOVA followed by Bonferroni correction for multiple comparisons with GraphPad Prism 5 software (San Diego, CA, USA). Statistical significance was set at the 0.05 probability level.

\section{Results}

We first evaluated the potential cytotoxicity of ONNV, PIC, IL- $\beta$ and CPT-11 on HSF. Basal levels of LDH $(<10 \%)$ were detected in the supernatant of control cells. ONNV at MOI 0.1 and 1 , but not PIC at $1 \mu \mathrm{g} / \mathrm{mL}$ and IL- $1 \beta$ at $10 \mathrm{ng} / \mathrm{mL}$, had cytotoxic effects on HSF evidenced by higher levels of LDH release ( $21 \%$ and $45 \%$, respectively) compared to control cells (Figure 1a). The expected cytotoxicity induced by ONNV was accompanied by an alteration of cell morphology (Figure S1A), the detection of viral RNA (E1 and nsP2 genes) in HSF (Figure S1B) and a decrease in MTT metabolism (Figure S1C). Concentrations of CPT-11 ranging from 0.15 to $15 \mu \mathrm{M}$ and covering the human plasma therapeutic range of 0.5 to $15 \mu \mathrm{M}$ to treat cancer $[20,21]$ were not cytotoxic for HSF (Figure $1 \mathrm{~b}$ ). We thus selected the highest concentration of $15 \mu \mathrm{M}$ to study the potential modulatory effects of CPT-11 on the antiviral and pro-inflammatory responses of HSF exposed to ONNV, PIC and IL- $1 \beta$. Of further note, this concentration of CPT-11 did not alter cell viability measured by the MTT assay (Figure S1D), as well as cell morphology (Figure S1E).

(a)

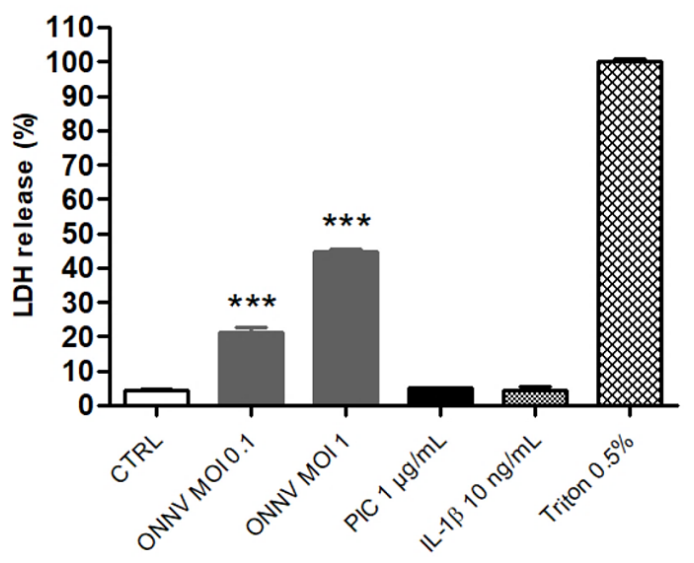

(b)

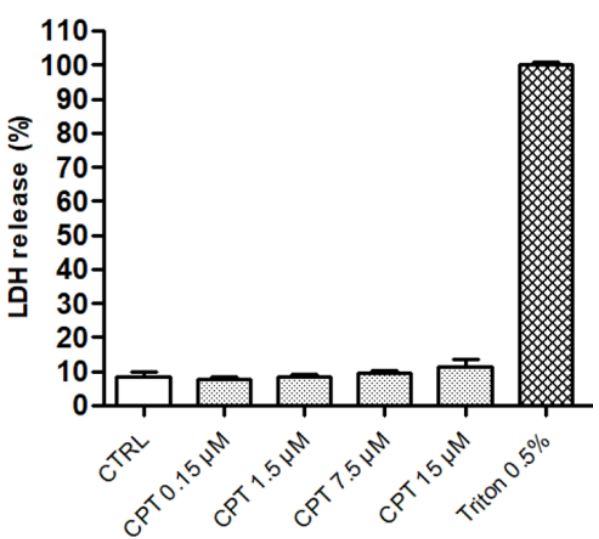

Figure 1. ONNV is cytotoxic for HSF. LDH activity was measured in culture supernatant $24 \mathrm{~h}$ after cell treatment with (a) ONNV at MOI 0.1 and 1, PIC at $1 \mu \mathrm{g} / \mathrm{mL}, \mathrm{IL}-1 \beta$ at $10 \mathrm{ng} / \mathrm{mL}$, and (b) CPT-11 at 0.15 to $15 \mu \mathrm{M}$. The percentage of cytotoxicity was calculated from the maximum LDH release following Triton X-100 exposure. Results are expressed as mean \pm SEM of four independent experiments. Statistical significance is indicated compared to control (CTRL), as follows: $p$-value $<0.001\left(^{* * *}\right)$.

As featured in Figure 2a, ISG15 gene expression was upregulated in HSF after $24 \mathrm{~h}$ of treatment with PIC and ONNV. CPT-11 did not significantly change ISG15 expression in control cells but increased it by 2-fold in PIC-but not in ONNV-stimulated cells (Figure 2b). We thought to determine whether CPT-11 had any effect on ONNV replication following cells' treatment with PIC. As shown in Figure S2A, a higher ISG15 expression was measured in HSF exposed to ONNV and after a $24 \mathrm{~h}$ co-stimulation with PIC and CPT-11 (compared 
to the stimulation with PIC alone). ONNV replication (monitored by RT-qPCR experiments for E1 and nsP2) was dramatically reduced in HSF previously treated with PIC (63-fold decrease and 15-fold decrease of E1 and nsP2 mRNA levels, respectively). This was probably due to high ISG levels initially induced by PIC. CPT-11 did not interfere with this major effect (Figure S2B,C).

(a)

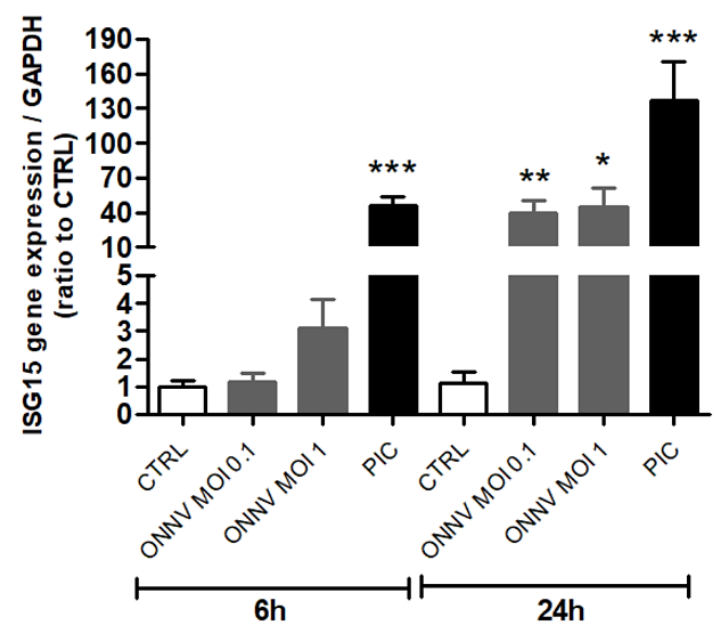

(b)

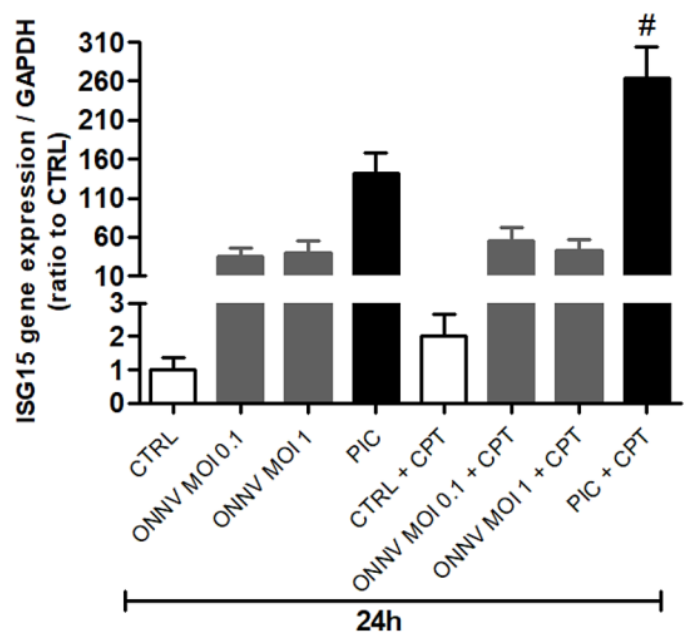

Figure 2. CPT enhances ISG15 gene expression in PIC-stimulated HSF. ISG15 mRNA levels from HSF treated with (a) ONNV (MOI 0.1 and 1) and PIC (1 $\mu \mathrm{g} / \mathrm{mL})$, and (b) co-treated with CPT-11 $(15 \mu \mathrm{M})$, for 6 and $24 \mathrm{~h}$, were evaluated by RT-qPCR. Results are expressed as mean \pm SEM of four independent experiments. Statistical significance is indicated as follows: $p$-value $<0.05\left(^{*}\right), p$-value $<0.01\left(^{* *}\right), p$-value $<0.001\left(^{* * *}\right)$ compared to control at the corresponding time of treatment; $p$-value $<0.05$ (\#) compared to the corresponding treatment without CPT-11.

Subsequently, we evaluated the expression of genes related to the antiviral response, including genes encoding for MDA5 (a nucleic acid sensor that recognizes viral long dsRNA mimicked here by PIC and that contributes to type I interferon expression [22]), IFN- $\beta$, STAT1 and STAT2 (two components of the transcription factor ISGF3 involved in ISGs production). RT-qPCR analysis revealed an upregulation of MDA5 and IFN- $\beta$ expression in HSF cultured in the presence of ONNV and PIC (Figure 3a,b). However, CPT-11 did not influence the expression of MDA5 and IFN- $\beta$ in both control and stimulated cells. STAT1 and STAT2 expression were significantly increased in cells exposed to PIC (by 4-fold and 3fold, respectively, compared to control cells) but not in cells exposed to ONNV (Figure 3c,d). CPT-11 significantly amplified STAT1 and STAT2 expression by 1.5-fold only in PIC-treated cells (Figure 3c,d). Overall, these results suggest that CPT-11 positively regulates ISG15 expression by improving type I interferon signaling rather than type I interferon expression itself in HSF stimulated with long dsRNA but not with whole alphaviruses.

We also analyzed the expression of the critical tumor suppressor gene p53 upon CPT11 treatment. Indeed, the ISG15 gene is known to be a p53-induced gene [23]. As shown in Figure 3e, ONNV and PIC significantly reduced p53 mRNA levels in HSF by 2.5-fold and 1.5-fold, respectively. PIC-induced ISG-15 up-regulation is thus not associated to p53 expression. CPT-11 increases p53 expression in control cells and in cells treated with ONNV but not in a significant manner. In PIC-treated cells, this expression was significantly higher in the presence of CPT-11 (2-fold increase). 
(a)

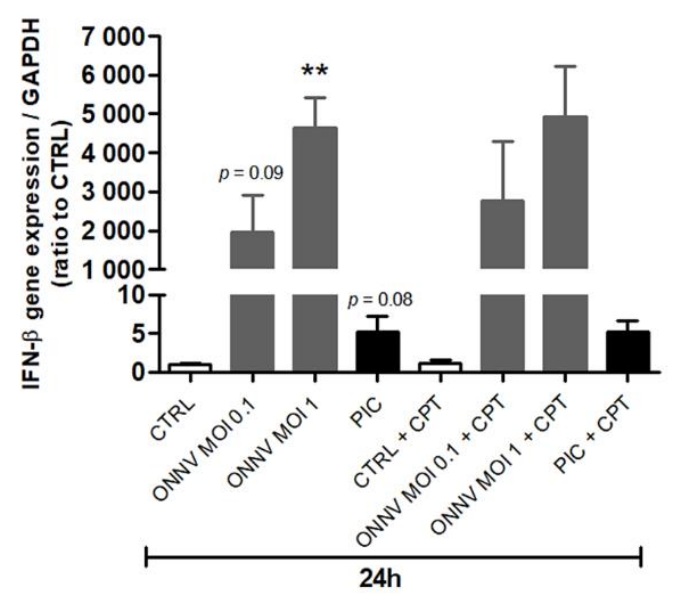

(c)

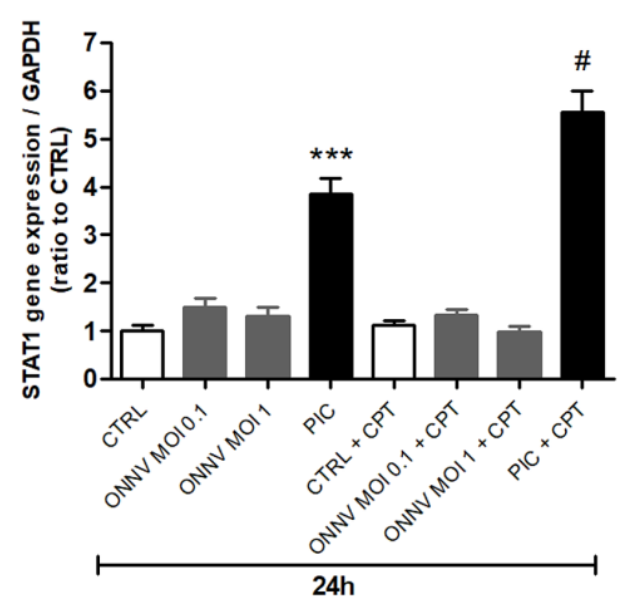

(e)

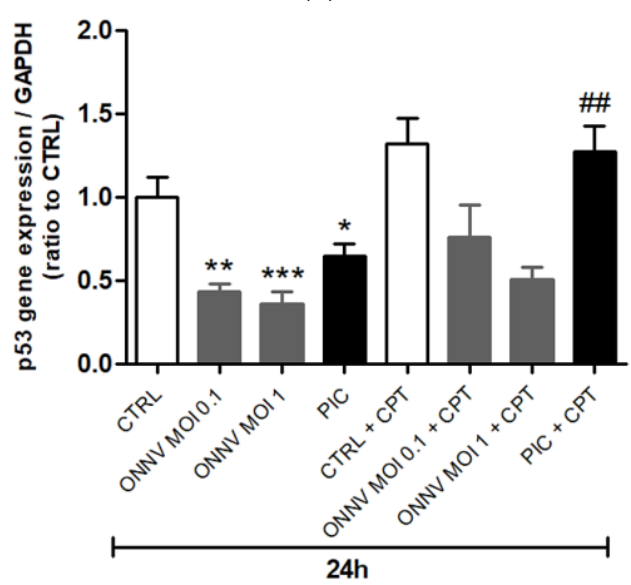

(b)

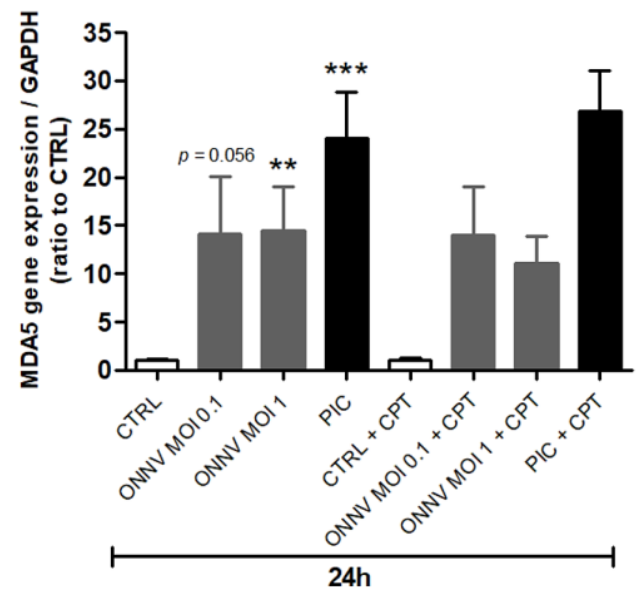

(d)

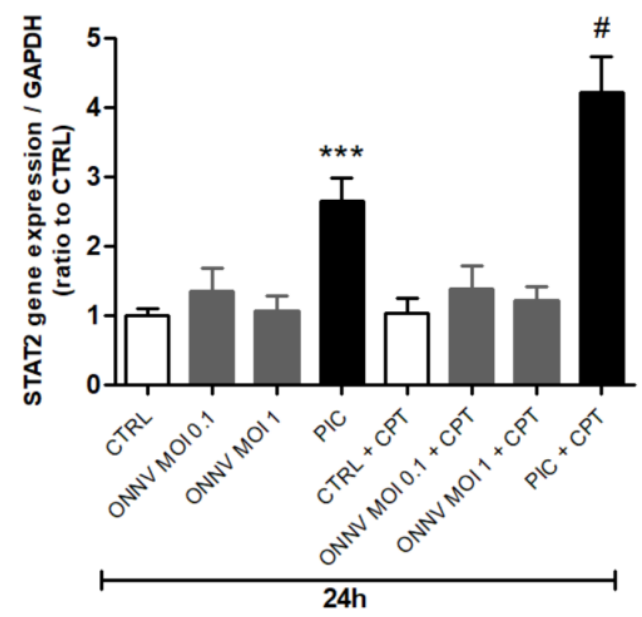

Figure 3. CPT-11 enhances STAT1, STAT2 and p53 (but not type I interferon and MDA5) gene expression in PIC-stimulated HSF. (a) IFN- $\beta$, (b) MDA5, (c) STAT1, (d) STAT2 and (e) p53 mRNA levels from HSF treated with ONNV and PIC and co-treated with CPT-11, for $24 \mathrm{~h}$, were evaluated by RT-qPCR. Results are expressed as mean \pm SEM of four independent experiments. Statistical significance is indicated as follows: $p$-value $<0.05\left(^{*}\right), p$-value $<0.01\left(^{* *}\right), p$-value $<0.001\left({ }^{* *}\right)$ compared to control at the corresponding time of treatment; $p$-value $<0.05$ (\#), $p$-value $<0.01$ (\#\#) compared to the corresponding treatment without CPT-11. 
Other ISGs were studied in cells simultaneously exposed to PIC and CPT-11. PICstimulated HSF displayed higher levels of ISG54 and $2^{\prime}-5^{\prime}$-oligoadenylate synthetase 1 (OAS1) mRNA and lower levels of protein kinase R (PKR) mRNA compared to control cells (Figure S3). Similar to the ISG15 RT-qPCR results, CPT-11 was responsible for an elevation of ISG54, OAS1 and PKR expression during PIC exposure, further confirming the role of this drug in the enhancement of antiviral gene expression.

We next investigated the potential effects of CPT-11 on the pro-inflammatory response of HSF cultured in the presence of ONNV and PIC. This response was also studied in HSF treated with IL-1 $\beta$, a cytokine involved in the pathogenesis of chronic and severe arthritis/arthralgia following alphaviral infection [24,25] and well-characterized to induce the expression of pro-inflammatory mediators, such as CXCL8, IL-6 and COX2, in synovial fibroblasts from patients with rheumatoid arthritis [26,27]. IL-1 $\beta$ was the most potent inducer of CXCL8, IL-6 and COX2 gene expression at $6 \mathrm{~h}$ of treatment compared to ONNV and PIC (Figure $4 \mathrm{a}-\mathrm{c}$ ). For instance, CXCL8 and COX2 expression levels were 60-fold and 20-fold higher, respectively, in IL-1 $\beta$ - than in PIC-stimulated HSF (Figure 4a,c). A reduced expression of CXCL8, IL-6 and COX2 was observed over time (at $24 \mathrm{~h}$ ) upon IL-1 $\beta$ treatment. ONNV and PIC modestly but significantly increased IL-6 and COX2 expression at $24 \mathrm{~h}$ of treatment (Figure $4 \mathrm{~b}, \mathrm{c}$ ). In unstimulated cells, CPT-11 significantly increased CXCL8 expression by 2-fold, while no effect of the drug occurred during PIC treatment and a 1.5-fold decreased expression was measured in IL-1 $\beta$ conditions (Figure $4 \mathrm{~d}$ ). CPT-11 did not influence CXCL8 secretion in control cells, suggesting that the increase in mRNA levels previously detected was not sufficient to generate a change at the protein level. Confirming RT-qPCR data, IL-1 $\beta$-induced CXCL8 secretion (72 $\pm 2 \mathrm{ng} / \mathrm{mL}$ versus $0.04 \pm 0.02 \mathrm{ng} / \mathrm{mL}$ in control condition) was significantly decreased up to $52 \pm 3 \mathrm{ng} / \mathrm{mL}$ by CPT-11 (Figure 5a). Of note, PIC-induced CXCL8 secretion $(0.6 \pm 0.1 \mathrm{ng} / \mathrm{mL}$ versus $0.04 \pm 0.02 \mathrm{ng} / \mathrm{mL}$ in control condition) was not modified by CPT-11 (data not shown). In contrast to CXCL8 results, CPT-11 had no effect on IL-6 gene expression in both unstimulated and stimulated cells (Figure 4e). Unexpectedly, ELISA revealed that IL-1 $\beta$-induced IL-6 secretion (112 $\pm 19 \mathrm{ng} / \mathrm{mL}$ versus $0.2 \pm 0.03 \mathrm{ng} / \mathrm{mL}$ in control condition) was significantly reduced at $59 \pm 11 \mathrm{ng} / \mathrm{mL}$ by CPT-11 (Figure $5 \mathrm{~b}$ ). This discrepancy with RT-qPCR analysis suggests that CPT-11 regulates not only transcriptional, but also post-transcriptional processes. Regarding COX-2, its expression in control cells was relatively low, although a 4-fold significant increase was detected after $24 \mathrm{~h}$ of stimulation with CPT-11. No major effect of the drug was observed upon PIC and ONNV treatments, whereas a 1.5-fold decreased gene expression was measured in IL- $1 \beta$ conditions (Figure $4 \mathrm{f}$ ). At the protein level, COX-2 was barely detectable by Western blot in control cells cultured with or without CPT-11. As expected, IL-1 $\beta$-induced COX-2 production was dampened by CPT-11 (Figure 5c,d). Our results indicate that this $\mathrm{CPT}$ analogue displays anti-inflammatory properties in stimulated HSF. This effect was not limited to the IL- $1 \beta$ treatment since, in the presence of TNF- $\alpha$ (another pro-inflammatory cytokine present during the chronic phase of alphavirus disease [28]), CPT-11 also reduced CXCL8 mRNA and protein levels by 1.6-fold and 3-fold, respectively (Figure S4A,B). Of note, COX-2 expression was not significantly upregulated by TNF- $\alpha$ (data not shown). 
(a)

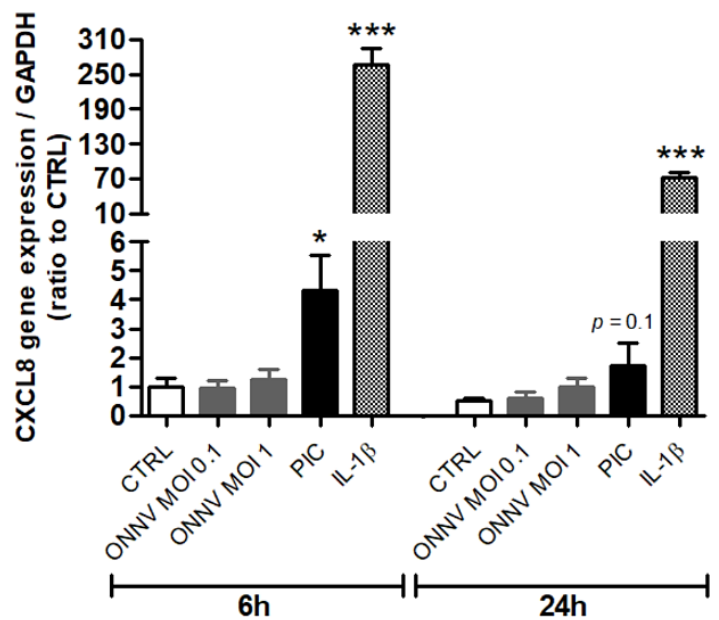

(c)

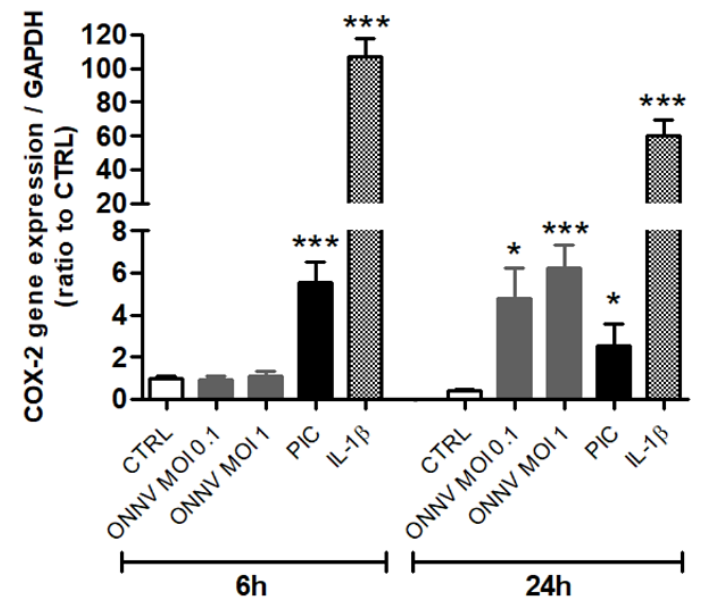

(e)
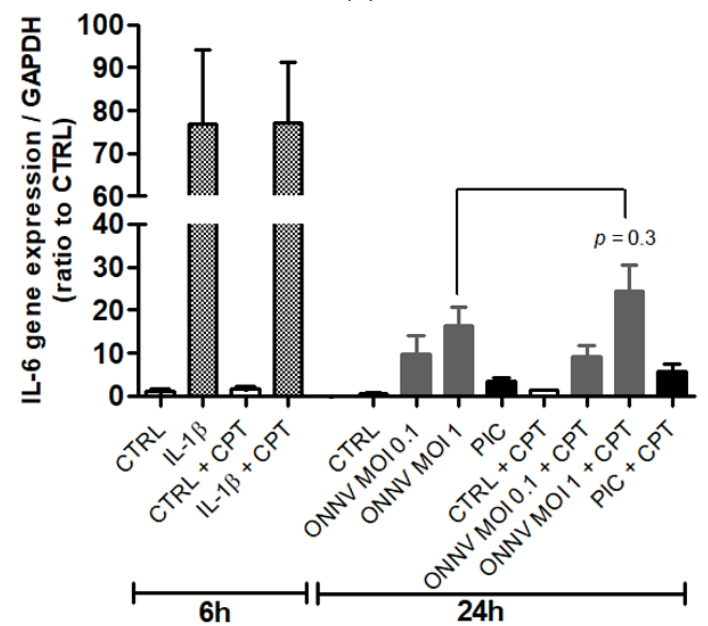

(b)

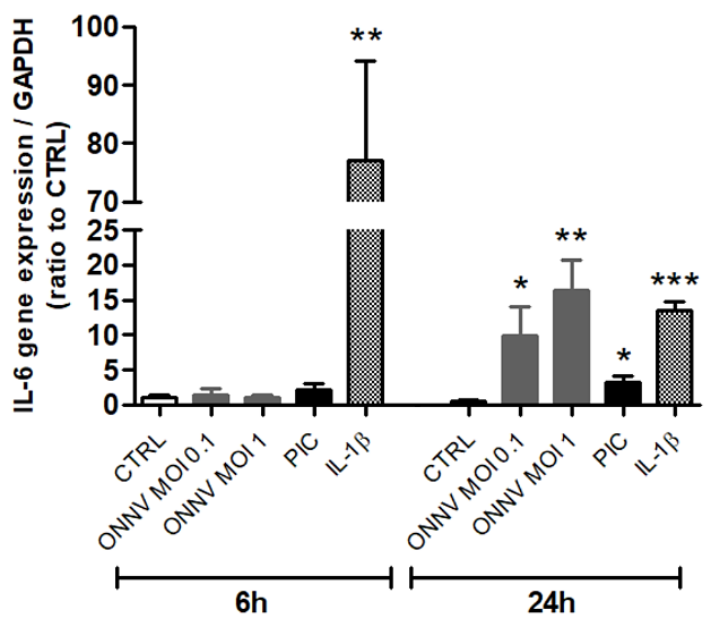

(d)

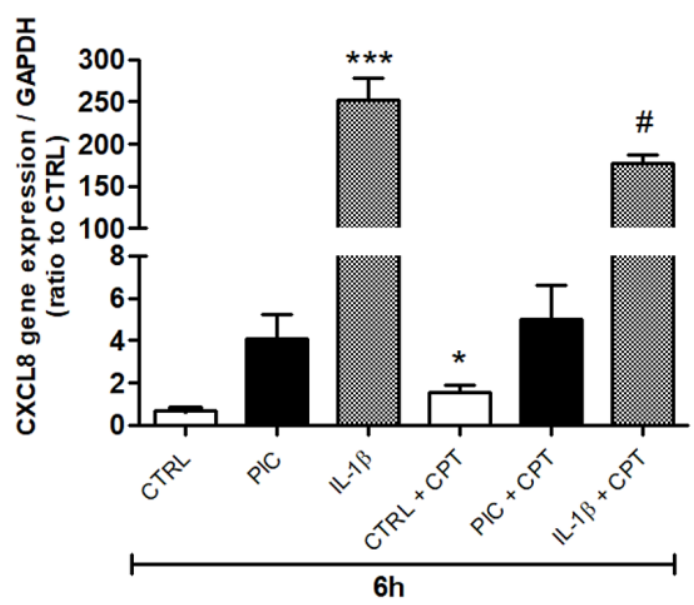

(f)

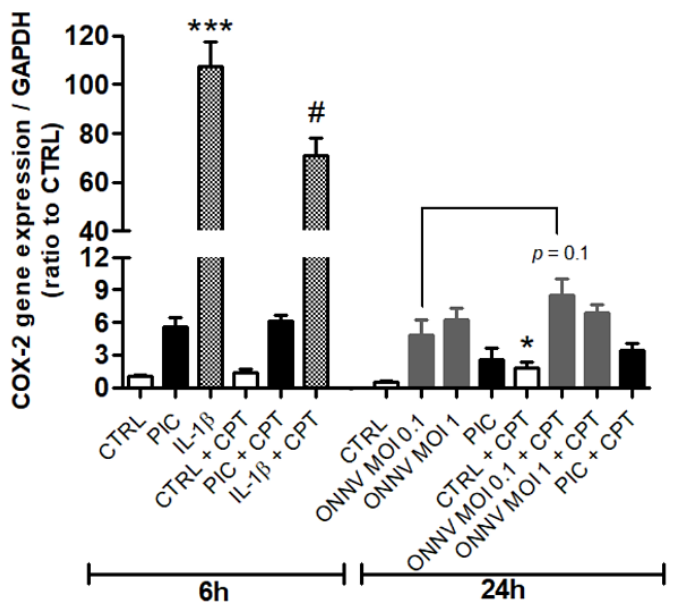

Figure 4. CPT-11 reduces IL-1 $\beta$-induced CXCL8 and COX-2 (but not IL-6) expression in HSF. (a) CXCL8, (b) IL-6 and (c) COX-2 mRNA levels from HSF treated with ONNV, PIC and IL-1 $\beta$, for 6 and $24 \mathrm{~h}$, were evaluated by RT-qPCR. (d) CXCL8, (e) IL-6 and (f) COX-2 mRNA levels were next assessed in HSF treated in the presence of CPT-11. Results are expressed as mean \pm SEM of four independent experiments. Statistical significance is indicated as follows: $p$-value $<0.05$ $\left.{ }^{*}\right), p$-value $\left.<0.01{ }^{* *}\right), p$-value $\left.<0.001{ }^{* * *}\right)$ compared to control at the corresponding time of treatment; $p$-value $<0.05$ (\#) compared to the corresponding treatment without CPT-11. 


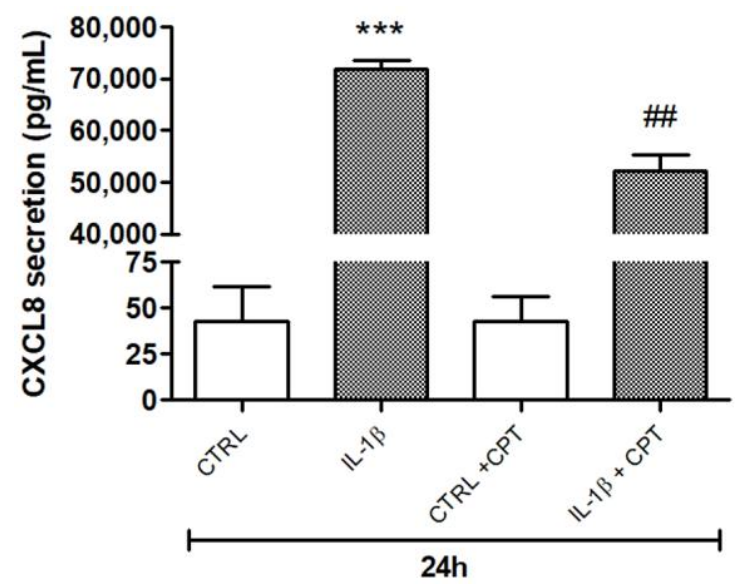

(a)

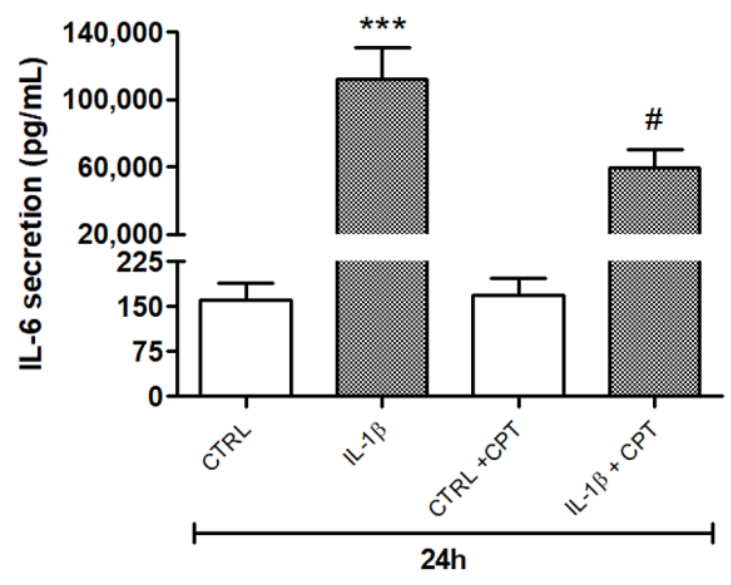

(b)

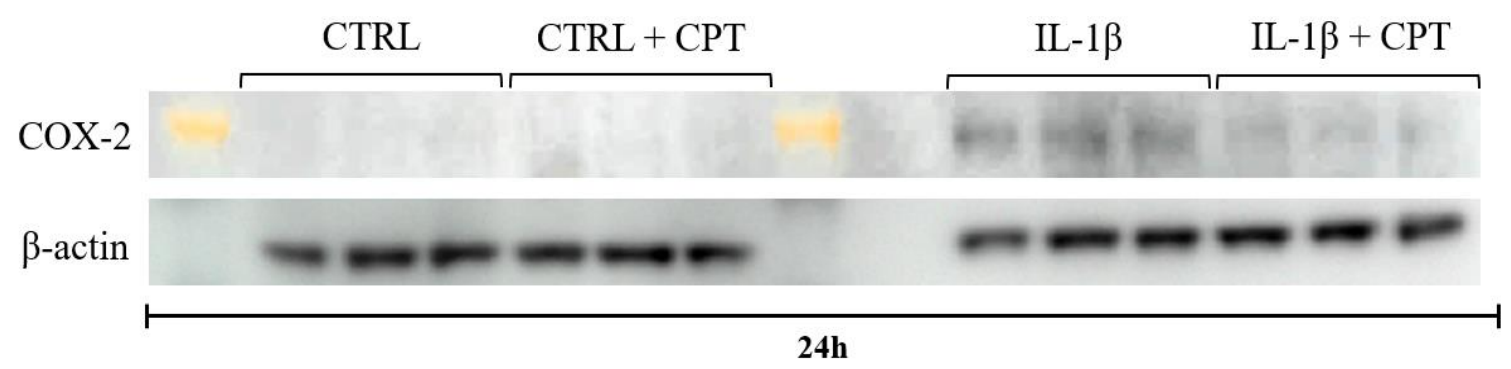

(c)

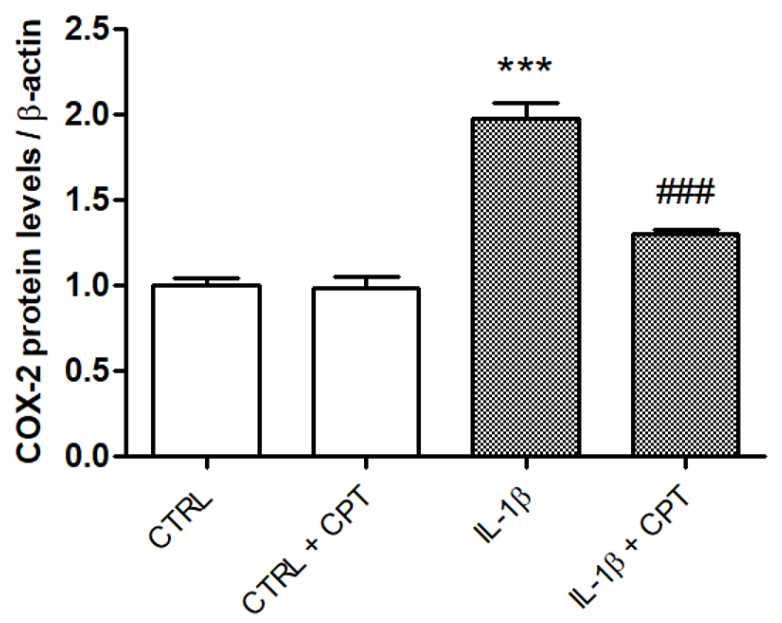

(d)

Figure 5. CPT-11 reduces IL-1 $\beta$-induced pro-inflammatory mediators' expression at the protein level, in HSF. (a) CXCL8 and (b) IL-6 secretion from HSF treated with IL-1 $\beta$ and co-treated with CPT-11, for $24 \mathrm{~h}$, were evaluated by ELISA in cell supernatants. (c) COX-2 intracellular protein levels were measured by Western blot $(n=3)$. The yellow mark indicates a molecular weight of $76 \mathrm{kDa}$ (from Amersham ECL Full-Range Rainbow Molecular Weight Markers, reference RPN800E). (d) Signal intensities from Western blot were quantified (arbitrary units). Quantitative results are expressed as mean \pm SEM. Statistical significance is indicated as follows: $p$-value $<0.001\left({ }^{* * *}\right)$ compared to control at the corresponding time of treatment; $p$-value $<0.05$ (\#), $p$-value $<0.01$ (\#\#), p-value $<0.001$ (\#\#\#) compared to the corresponding treatment without CPT-11. 
As the antagonistic pathways NF- $\mathrm{kB}$ and p53 predominantly modulate inflammation in synovial fibroblasts in the context of rheumatoid arthritis [26,29], RT-qPCR experiments were carried out to assess the expression of these two transcription factors. IL-1 $\beta$ markedly increased NF-KB1 gene expression (by 8 -fold) at $6 \mathrm{~h}$ of treatment and this effect was completely blunted over time (at $24 \mathrm{~h}$ ). CPT-11 did not modulate NF-kB1 expression in control cells but down-regulated it by 1.5 -fold and in a significant manner in cells exposed to IL-1 $\beta$ (Figure 6a). The expression level of p53 was reduced by 1.6-fold and 3-fold in IL-1 $\beta$-stimulated cells compared to control cells, at 6 and $24 \mathrm{~h}$ of treatment, respectively. IL-1 $\beta$-induced decrease in p53 expression was significantly rescued by CPT-11 (2.4-fold increase) at $24 \mathrm{~h}$ (Figure $6 \mathrm{~b}$ ). These results corroborate the anti-inflammatory effects of CPT-11 on HSF cultured in the presence of IL- $1 \beta$.

(a)

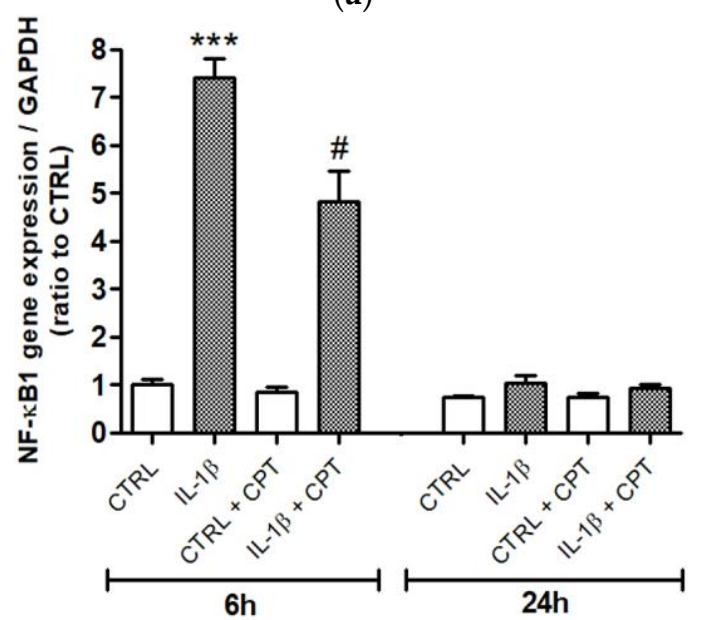

(b)

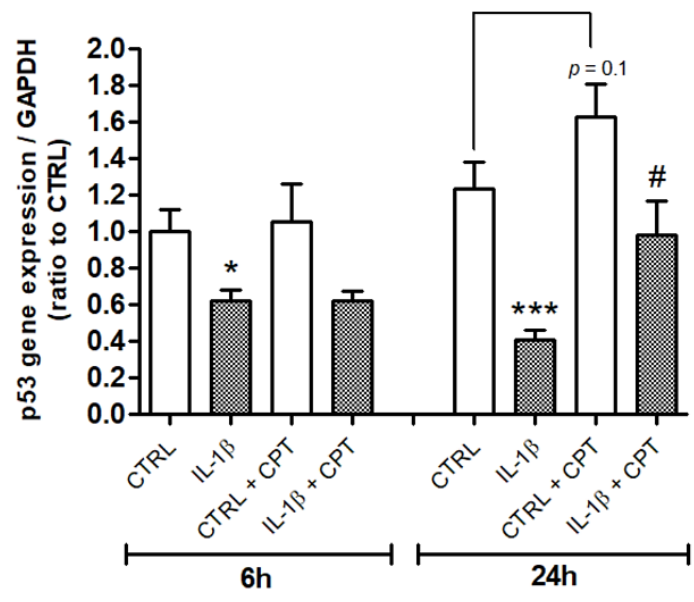

Figure 6. CPT-11 down-regulates IL-1 $\beta$-induced NF- $\kappa$ B1 expression and upregulates an IL- $1 \beta$-induced decrease in p53 expression in HSF. (a) NF-kB1 and (b) p53 mRNA levels from HSF treated with IL-1 $\beta$ and co-treated with CPT-11, for 6 and $24 \mathrm{~h}$, were evaluated by RT-qPCR. Results are expressed as mean \pm SEM of four independent experiments. Statistical significance is indicated as follows: $p$-value $<0.05\left(^{*}\right), p$-value $<0.001\left(^{* * *}\right)$ compared to control at the corresponding time of treatment; $p$-value $<0.05$ (\#) compared to the corresponding treatment without CPT- 11 .

\section{Discussion}

Infection with alphaviruses is characterized by a viremia usually lasting $5-7$ days and following a 2-6-day incubation period in adults. Acute disease is associated with a strong type I interferon response leading to ISG expression. While many patients with acute alphavirus (CHIKV) infection recover, $1.6-57 \%$ of them develop chronic arthritic disease that remains unresolved for up to several years [30,31]. The molecular mechanisms involved in the transition from acute to chronic pathology are still unclear. Persistence of viral antigens in synovial tissue and prolonged inflammation are thought to contribute to disease progression. Of critical note, viral dsRNA was detected in the joint of a human clinical case report, 18 months post-infection by CHIKV [32]. Moreover, the presence of arthritogenic dsRNA was confirmed in the synovial fluid from chronic rheumatoid arthritis patients with an erosive disease course [33]. The majority of all viruses produce dsRNA during their replication in host cells. In our model, PIC was thus applied to synovial fibroblasts to mimic, in general, the presence of dsRNA in the joint during the chronic phase of viral arthritic disease. There is currently no treatment or vaccine specific for alphavirus infection and, moreover, a previous investigation of our group revealed that the disease-modifying anti-rheumatic drug methotrexate had no effect on the antiviral and pro-inflammatory response of synovial fibroblasts exposed to PIC [34]. The originality of the present study was to evaluate the repositioning of the anti-cancer molecule CPT11 (a semisynthetic analogue of camptothecin) in the context of viral arthritis. At the non-toxic concentration of $10 \mu \mathrm{g} / \mathrm{mL}(15 \mu \mathrm{M})$, we found that CPT-11 enhances antiviral 
gene expression (ISGs) in HSF treated with PIC (but not with ONNV). PIC is a synthetic analogue of viral double-stranded RNA, while alphavirus, in addition to be composed of RNA, also contains many other molecules such as nonstructural proteins (nsP). Among these proteins, nsP2 and nsP3 were found to inhibit host antiviral pathways. For instance, nsP2 decreases ISG expression by promoting transcriptional shutoff by degradation of RNA polymerase subunit RPB1 and by blocking the IFN-induced JAK-STAT pathway [35]. This may explain why mRNA levels of ISG15, STAT1 and STAT2 were not increased by CPT-11 after ONNV stimulation.

The enhanced ISG expression mediated by CPT-11 upon PIC treatment was associated with increased gene expression of STAT1 and STAT2, described to be involved in ISG expression. In line with our results, higher levels of ISG15 were evidenced in human fibrosarcoma cells in response to camptothecin, as well as the requirement of p53 in this mechanism [36]. In their genome-wide transcriptional analysis, Veloso and collaborators showed that interferon regulatory factors (IRFs), including IRF1, IRF3 and IRF9, were upregulated in human fibroblasts after $7 \mu \mathrm{g} / \mathrm{mL}$ CPT exposure (16). IRF1 and IRF3 are positive regulators of type I interferon gene induction $[37,38]$. Although we did not measure the expression of these two transcription factors in our model, we found no variation of IFN- $\beta$ mRNA levels upon CPT-11 treatment. Upregulation of ISG expression in HSF could be linked to IRF1-stimulated p53 activity, as demonstrated in the human colon cancer cell line HCT116 [39], and/or p53 ISGylation that forms a positive feedback loop for its transcriptional activation [40], and/or increased ISGF3 production dependent on IRF9, STAT1 and STAT2 intracellular amounts.

Regarding inflammation, data about CPT and its derivatives are still unclear. Indeed, it has been demonstrated that CPT and CPT-11 induce activation of the NF- $\mathrm{B}$ pathway in a variety of human carcinoma cell lines, a mechanism thought to contribute to resistance to chemotherapy [41-43]. In addition, SN38, the active metabolite of CPT-11, has been shown to increase CXCL8 secretion by enhancing the phosphorylation of MAP kinases in HCT8 cells [44]. By contrast, Riedlinger et al. evidenced that topoisomerase I inhibitors interfere with cytokine-induced and NF- $\mathrm{kB}$ p65-mediated inflammatory gene expression in a variety of cell lines [45]. In human fibroblasts, CPT was found to increase the expression of NFKBIE and NFKBIB genes (encoding for the NF- $\kappa$ B inhibitors I $\kappa \mathrm{B}-\varepsilon$ and I $\kappa \mathrm{B}-\beta$, respectively) and decrease the expression of the IKBKB gene (encoding for the NF- $\kappa B$ activator IKK- $\beta$ ) [16]. In support to these latest findings, our data revealed that the expression of NFKB1 gene (encoding for the p105 subunit, precursor of the p50 subunit) was down-regulated in HSF co-treated with IL-1 $\beta$ and CPT- 11 . This result correlated with reduced CXCL8 and COX-2 mRNA and protein levels, whereas the secretion of IL-6 (a biomarker, among others, of arthralgia/arthritis persistence and severity following alphaviral infection $[28,46]$ ) appeared to be modulated at the post-transcriptional level. In this sense, post-transcriptional-level interactions between NF- $\mathrm{BB}$ and the Lin28/let-7 pathway were recently described in the review written by Mills IV et al. and showed that NF- $\mathrm{BB}$ mediates Lin28b expression, an inhibitor of Let-7 miRNA family members, themselves known to reduce IL-6 production by interfering with the $3^{\prime}$ UTR region of its mRNA [47]. This review also evidences many predicted interactions between let-7 miRNA and mRNA related to NF- $\mathrm{kB}$ subunits, including, among others, interactions that repress p105 mRNA. Interestingly, several natural compounds (polyphenols and indole alkaloids) have been documented to intensify let-7 expression $[48,49]$. Further investigations are required to determine whether CPT and its analogues are able to modulate the NF- $\mathrm{KB} / \mathrm{Lin} 28 /$ Let-7 pathway, as new miRNA-based therapies could be developed in the context of viral arthritis, but also other inflammatory diseases, such as autoimmune diseases, type 2 diabetes and obesity. Complementary studies should be also performed on the tumor suppressor gene p53. We found that the IL-1 $\beta$-induced decrease in p53 expression was abolished by CPT-11, a result consistent with reduced CXCL8, IL-6 and COX-2 levels. Indeed, p53 and NF- $\mathrm{kB}$ function as mutual inhibitors. Zhang and collaborators established that p53 deficiency increased the phosphorylation rate of IkB- $\alpha$ and MAP kinases in fibroblast-like 
synoviocytes treated with IL-1 $\beta$, leading to higher IL-6 secretion [29]. Of important note, the dual-specificity phosphatase 5 (DUSP5) gene, a direct target of p53, is upregulated in human fibroblasts, after CPT exposure [16]. DUSP5 is known to be induced in response to MAP kinase activation $[50,51]$ and acts as a negative feedback regulator of MAP kinases and NF- $\mathrm{KB}$ signaling pathways in a phosphatase activity-dependent or -independent manner [52,53]. Although we did not analyze DUSP5 and MAP kinase expression in our model, it is likely that the level of HSF stimulation in the presence of IL- $1 \beta$ is sufficiently high for DUSP5 to be expressed and to act by inhibiting NF- $\mathrm{kB}$ and MAP kinase pathways.

In conclusion, CPT- 11 appears to be an interesting molecule, particularly in the context of chronic and severe arthritis due to viral infection. Indeed, this drug acts both as a potentiator of the antiviral response of HSF exposed to PIC and as an inhibitor of inflammation after IL-1 $\beta$ exposure. Further studies are warranted to address whether CPT- 11 is able to modulate these responses in T cells and macrophages (also present in the synovial tissue of patients with infectious chronic inflammatory rheumatisms). This work also highlights that modulators of NF- $\mathrm{KB}$ and p53 could be therapeutically useful for the treatment of arthritis. Currently, the most common forms of administration of CPT-11 in patients are 30- or 90-min intravenous infusions of $125 \mathrm{mg} / \mathrm{m}^{2}$ given weekly for 4 of every 6 weeks (North America), or $350 \mathrm{mg} / \mathrm{m}^{2}$ given every 3 weeks (Europe) [54]. Although CPT-11 was not toxic for cultured HSF over the entire human therapeutic range, the molecule is often associated with intestinal mucosal injury and clinically significant diarrhea [55]. To reduce the CPT-11-linked systemic side effect, co-therapy with polyphenols could be envisaged. For instance, the protective effect of curcumin against irinotecan-induced intestinal mucosal injury was evidenced in nude mice [56]. Another strategy would be the local, controlled delivery of CPT-11 (in the case of arthritis, in the articular synovium) loaded in polymers, such as ethylene-vinyl acetate co-polymer [57].

Supplementary Materials: The following are available online at https://www.mdpi.com/article/ 10.3390/cells10061431/s1, Figure S1: ONNV can replicate in HSF and alters cell viability. CPT-11 at $15 \mu \mathrm{M}$ does not affect cell viability, Figure S2: CPT-11 does not interfere with the blunted ONNV replication observed in HSF previously exposed to PIC, Figure S3: CPT-11 enhances several ISGs' expression in PIC-stimulated HSF, Figure S4: CPT-11 reduces TNF- $\alpha$-induced CXCL8 expression.

Author Contributions: Conceptualization, P.G. (Philippe Gasque), P.G. (Pascale Guiraud) and J.S.; Data curation, A.D.; Formal analysis, A.D.; Funding acquisition, P.G. (Philippe Gasque), P.G. (Pascale Guiraud) and J.S.; Investigation, A.D., P.G. (Philippe Gasque), P.G. (Pascale Guiraud) and J.S.; Methodology, A.D. and P.G. (Philippe Gasque); Project administration, P.G. (Philippe Gasque) and J.S.; Resources, P.G. (Philippe Gasque), P.G. (Pascale Guiraud) and J.S.; Software, A.D. and P.G. (Philippe Gasque); Supervision, P.G. (Philippe Gasque) and J.S.; Validation, P.G. (Philippe Gasque), P.G. (Pascale Guiraud) and J.S.; Visualization, A.D., P.G. (Philippe Gasque), P.G. (Pascale Guiraud) and J.S.; Writing—original draft, A.D.; Writing—review and editing, P.G. (Philippe Gasque), P.G. (Pascale Guiraud) and J.S. All authors have read and agreed to the published version of the manuscript.

Funding: This research was funded by the Regional Council of La Réunion, and State of France: CPER-FEDER (Contrat de Plan État-Région-Fonds Européens de Développement Régional), VIROPAM Program.

Data Availability Statement: The data presented in this study are available in article.

Acknowledgments: The authors thank all other members of the EPI laboratory.

Conflicts of Interest: The authors declare no conflict of interest. The funders had no role in the design of the study; in the collection, analyses, or interpretation of data; in the writing of the manuscript, or in the decision to publish the results.

\section{References}

1. Marks, M.; Marks, J.L. Viral arthritis. Clin. Med. 2016, 16, 129. [CrossRef]

2. Gould, E.A.; Higgs, S. Impact of climate change and other factors on emerging arbovirus diseases. Trans. R. Soc. Trop. Med. Hyg. 2009, 103, 109-121. [CrossRef]

3. Weaver, S.C.; Lecuit, M. Chikungunya virus infections. N. Engl. J. Med. 2015, 373, 93-95. 
4. Kurkela, S.; Manni, T.; Myllynen, J.; Vaheri, A.; Vapalahti, O. Clinical and laboratory manifestations of Sindbis virus infection: Prospective study, Finland, 2002-2003. J. Infect. Dis. 2005, 191, 1820-1829. [CrossRef] [PubMed]

5. Borgherini, G.; Poubeau, P.; Jossaume, A.; Gouix, A.; Cotte, L.; Michault, A.; Arvin-Berod, C.; Paganin, F. Persistent arthralgia associated with chikungunya virus: A study of 88 adult patients on reunion island. Clin. Infect. Dis. 2008, 47, 469-475. [CrossRef] [PubMed]

6. Mostafavi, H.; Abeyratne, E.; Zaid, A.; Taylor, A. Arthritogenic alphavirus-induced immunopathology and targeting host inflammation as a therapeutic strategy for alphaviral disease. Viruses 2019, 11, 290. [CrossRef] [PubMed]

7. Chaaitanya, I.K.; Muruganandam, N.; Sundaram, S.G.; Kawalekar, O.; Sugunan, A.P.; Manimunda, S.P.; Ghosal, S.R.; Muthumani, K.; Vijayachari, P. Role of proinflammatory cytokines and chemokines in chronic arthropathy in CHIKV infection. Viral Immunol. 2011, 24, 265-271. [CrossRef]

8. Phuklia, W.; Kasisith, J.; Modhiran, N.; Rodpai, E.; Thannagith, M.; Thongsakulprasert, T.; Smith, D.R.; Ubol, S. Osteoclastogenesis induced by CHIKV-infected fibroblast-like synoviocytes: A possible interplay between synoviocytes and monocytes/macrophages in CHIKV-induced arthralgia/arthritis. Virus Res. 2013, 177, 179-188. [CrossRef]

9. Troost, B.; Mulder, L.M.; Diosa-Toro, M.; van de Pol, D.; Rodenhuis-Zybert, I.A.; Smit, J.M. Tomatidine, a natural steroidal alkaloid shows antiviral activity towards chikungunya virus in vitro. Sci. Rep. 2020, 10, 6364. [CrossRef]

10. Li, R.; Liu, T.; Liu, M.; Chen, F.; Liu, S.; Yang, J. Anti-influenza a virus activity of dendrobine and its mechanism of action. J. Agric. Food Chem. 2017, 65, 3665-3674. [CrossRef] [PubMed]

11. Whitby, K.; Pierson, T.C.; Geiss, B.; Lane, K.; Engle, M.; Zhou, Y.; Doms, R.W.; Diamond, M.S. Castanospermine, a potent inhibitor of dengue virus infection in vitro and in vivo. J. Virol. 2005, 79, 8698-8706. [CrossRef]

12. Bin Kang, K.; Ming, G.; Kim, G.J.; Ha, T.-K.-Q.; Choi, H.; Oh, W.K.; Sung, S.H. Jubanines F-J, cyclopeptide alkaloids from the roots of Ziziphus jujuba. Phytochemistry 2015, 119, 90-95. [CrossRef] [PubMed]

13. Pantazis, P.; Han, Z.; Chatterjee, D.; Wyche, J. Water-insoluble camptothecin analogues as potential antiviral drugs. J. Biomed. Sci. 1999, 6, 1-7. [CrossRef] [PubMed]

14. Kelly, D.C.; Avery, R.J.; Dimmock, N.J. Camptothecin: An inhibitor of influenza virus replication. J. Gen. Virol. 1974, $25,427-432$. [CrossRef] [PubMed]

15. Bennett, R.P.; Stewart, R.A.; Hogan, P.A.; Ptak, R.G.; Mankowski, M.K.; Hartman, T.L.; Buckheit, R.W.; Snyder, B.A.; Salter, J.D.; Morales, G.A.; et al. An analog of camptothecin inactive against Topoisomerase I is broadly neutralizing of HIV-1 through inhibition of Vif-dependent APOBEC3G degradation. Antivir. Res. 2016, 136, 51-59. [CrossRef]

16. Veloso, A.; Biewen, B.; Paulsen, M.T.; Berg, N.; Lima, L.C.D.A.; Prasad, J.; Bedi, K.; Magnuson, B.; Wilson, T.E.; Ljungman, M. Genome-wide transcriptional effects of the anti-cancer agent camptothecin. PLoS ONE 2013, 8, e78190. [CrossRef]

17. Bailly, C. Irinotecan: 25 years of cancer treatment. Pharmacol. Res. 2019, 148, 104398. [CrossRef]

18. VanLandingham, D.L.; Higgs, S.; Hong, C.; Klingler, K.A.; McElroy, K.L.; Lehane, M.J.; Tsetsarkin, K. Determinants of vector specificity of o'nyong nyong and chikungunya viruses in Anopheles and Aedes mosquitoes. Am. J. Trop. Med. Hyg. 2006, 74, 663-669. [CrossRef]

19. Livak, K.J.; Schmittgen, T.D. Analysis of relative gene expression data using real-time quantitative PCR and the $2-\Delta \Delta C T$ method. Methods 2001, 25, 402-408. [CrossRef]

20. Idili, A.; Arroyo-Curras, N.; Ploense, K.L.; Csordas, A.T.; Kuwahara, M.; Kippin, T.E.; Plaxco, K.W. Seconds-resolved pharmacokinetic measurements of the chemotherapeutic irinotecan in situ in the living body. Chem. Sci. 2019, 10, 8164-8170. [CrossRef]

21. Chabot, G.G. Clinical pharmacokinetics of irinotecan. Clin. Pharmacokinet. 1997, 33, 245-259. [CrossRef] [PubMed]

22. Saito, T.; Gale, M., Jr. Differential recognition of double-stranded RNA by RIG-I-like receptors in antiviral immunity. J. Exp. Med. 2008, 205, 1523-1527. [CrossRef]

23. Polyak, K.; Xia, Y.; Zweier, J.L.; Kinzler, K.W.; Vogelstein, B. A model for p53-induced apoptosis. Nature 1997, 389, 300-305. [CrossRef]

24. Assuncão-Miranda, I.; Cruz-Oliveira, C.; Da Poian, A.T. Molecular mechanisms involved in the pathogenesis of alphavirusinduced arthritis. Biomed. Res. Int. 2013, 2013, 973516. [CrossRef]

25. Amaral, J.K.; Taylor, P.C.; Teixeira, M.M.; Morrison, T.E.T.; Schoen, R.T. The clinical features, pathogenesis and methotrexate therapy of chronic chikungunya arthritis. Viruses 2019, 11, 289. [CrossRef]

26. Georganas, C.; Liu, H.; Perlman, H.; Hoffmann, A.; Thimmapaya, B.; Pope, R.M. Regulation of IL-6 and IL-8 expression in rheumatoid arthritis synovial fibroblasts: The dominant role for NF-kappa B but not C/EBP beta or c-Jun. J. Immunol. 2000, 165, 7199-7206. [CrossRef] [PubMed]

27. Kapoor, M.; Kojima, F.; Crofford, L. Arachidonic acid-derived eicosanoids in rheumatoid arthritis: Implications and future targets. Future Rheumatol. 2006, 1, 323-330. [CrossRef]

28. Ninla-Aesong, P.; Mitarnun, W.; Noipha, K. Proinflammatory cytokines and chemokines as biomarkers of persistent arthralgia and severe disease after chikungunya virus infection: A 5-year follow-up study in Southern Thailand. Viral Immunol. 2019, 32, 442-452. [CrossRef]

29. Zhang, T.; Li, H.; Shi, J.; Li, S.; Li, M.; Zhang, L.; Zheng, L.; Zheng, D.; Tang, F.; Zhang, X.; et al. p53 predominantly regulates IL-6 production and suppresses synovial inflammation in fibroblast-like synoviocytes and adjuvant-induced arthritis. Arthritis Res. Ther. 2016, 18, 271. [CrossRef] [PubMed] 
30. Suhrbier, A.; Jaffar-Bandjee, M.C.; Gasque, P. Arthritogenic alphaviruses-an overview. Nat. Rev. Rheumatol. 2012 , 8, 420-429. [CrossRef]

31. Zaid, A.; Gérardin, P.; Taylor, A.; Mostafavi, H.; Malvy, D.; Mahalingam, S. Review: Chikungunya arthritis: Implications of acute and chronic inflammation mechanisms on disease management. Arthritis Rheumatol. 2018, 70, 484-495. [CrossRef] [PubMed]

32. Hoarau, J.J.; Jaffar Bandjee, M.C.; Krejbich Trotot, P.; Das, T.; Li-Pat-Yuen, G.; Dassa, B.; Denizot, M.; Guichard, E.; Ribera, A.; Henni, T.; et al. Persistent chronic inflammation and infection by Chikungunya arthritogenic alphavirus in spite of a robust host immune response. J. Immunol. 2010, 184, 5914-5927. [CrossRef] [PubMed]

33. Bokarewa, M.; Tarkowski, A.; Lind, M.; Dahlberg, L.; Magnusson, M. Arthritogenic dsRNA is present in synovial fluid from rheumatoid arthritis patients with an erosive disease course. Eur. J. Immunol. 2008, 38, 3237-3244. [CrossRef]

34. Bedoui, Y.; Giry, C.; Jaffar-Bandjee, M.C.; Selambarom, J.; Guiraud, P.; Gasque, P. Immunomodulatory drug methotrexate used to treat patients with chronic inflammatory rheumatisms post-chikungunya does not impair the synovial antiviral and bone repair responses. PLoS Negl. Trop. Dis. 2018, 12, e0006634. [CrossRef] [PubMed]

35. Fros, J.J.; Pijlman, G.P. Alphavirus infection: Host cell shut-off and inhibition of antiviral responses. Viruses 2016, 8, 166. [CrossRef]

36. Liu, M.; Hummer, B.T.; Li, X.; Hassel, B.A. Camptothecin induces the ubiquitin-like protein, ISG15, and enhances ISG15 conjugation in response to interferon. J. Interferon Cytokine Res. 2004, 24, 647-654. [CrossRef]

37. Jefferies, C.A. Regulating IRFs in IFN driven disease. Front. Immunol. 2019, 10, 325. [CrossRef]

38. Honda, K.; Takaoka, A.; Taniguchi, T. Type I interferon gene induction by the interferon regulatory factor family of transcription factors. Immunity 2006, 25, 349-360. [CrossRef]

39. Dornan, D.; Eckert, M.; Wallace, M.; Shimizu, H.; Ramsay, E.; Hupp, T.R.; Ball, K.L. Interferon regulatory factor 1 binding to p300 stimulates DNA-dependent acetylation of p53. Mol. Cell. Biol. 2004, 24, 10083-10098. [CrossRef] [PubMed]

40. Jeon, Y.J.; Park, J.H.; Chung, C.H. Interferon-stimulated gene 15 in the control of cellular responses to genotoxic stress. Mol. Cells 2017, 40, 83-89. [CrossRef]

41. Guo, J.; Verma, U.N.; Gaynor, R.B.; Frenkel, E.P.; Becerra, C.R. Enhanced chemosensitivity to irinotecan by RNA interferencemediated down-regulation of the nuclear factor-kappaB p65 subunit. Clin. Cancer Res. 2004, 10, 3333-3341. [CrossRef]

42. Seo, S.H.; Kim, S.G.; Shin, J.H.; Ham, D.W.; Shin, E.H. Toxoplasma GRA16 inhibits NF-kappaB activation through PP2A-B55 upregulation in non-small-cell lung carcinoma cells. Int. J. Mol. Sci. 2020, 21, 6642. [CrossRef]

43. Chowdhury, R.; Gales, D.; Valenzuela, P.; Miller, S.; Yehualaeshet, T.; Manne, U.; Francia, G.; Samuel, T. Bromoethylindole (BEI-9) redirects NF-kB signaling induced by camptothecin and TNF $\alpha$ to promote cell death in colon cancer cells. Apoptosis 2017, 22, 1553-1563. [CrossRef] [PubMed]

44. Zhang, L.; Lou, W.-H.; Xu, X.-F.; Wu, W.; Rong, Y.-F.; Jin, D.-Y. SN38 increases IL-8 expression through the MAPK pathways in HCT8 cells. Int. J. Mol. Med. 2016, 39, 217-222. [CrossRef] [PubMed]

45. Riedlinger, T.; Bartkuhn, M.; Zimmermann, T.; Hake, S.B.; Nist, A.; Stiewe, T.; Kracht, M.; Schmitz, M.L. Chemotherapeutic drugs inhibiting topoisomerase 1 activity impede cytokine-induced and NF-kappaB p65-regulated gene expression. Cancers 2019, 11, 883. [CrossRef]

46. Ng, L.F.; Chow, A.; Sun, Y.J.; Kwek, D.J.; Lim, P.L.; Dimatatac, F.; Ng, L.C.; Ooi, E.E.; Choo, K.H.; Her, Z.; et al. IL-1ß, IL-6, and RANTES as biomarkers of Chikungunya severity. PLoS ONE 2009, 4, e4261. [CrossRef]

47. Mills, W.T.; Nassar, N.N.; Ravindra, D.; Li, X.; Meffert, M.K. Multi-level regulatory interactions between NF-kB and the pluripotency factor Lin28. Cells 2020, 9, 2710. [CrossRef]

48. Li, Y.; VandenBoom, T.G., II; Kong, D.; Wang, Z.; Ali, S.; Philip, P.A.; Sarkar, F.H. Up-regulation of miR-200 and let-7 by natural agents leads to the reversal of epithelial-to-mesenchymal transition in gemcitabine-resistant pancreatic cancer cells. Cancer Res. 2009, 69, 6704-6712. [CrossRef] [PubMed]

49. Phuah, N.H.; Nagoor, N.H. Regulation of MicroRNAs by natural agents: New strategies in cancer therapies. BioMed Res. Int. 2014, 2014, 804510. [CrossRef]

50. Buffet, C.; Catelli, M.-G.; Hecale-Perlemoine, K.; Bricaire, L.; Garcia, C.; Gallet-Dierick, A.; Rodriguez, S.; Cormier, F.; Groussin, L. Dual specificity phosphatase 5, a specific negative regulator of ERK signaling, is induced by serum response factor and Elk-1 transcription factor. PLoS ONE 2015, 10, e0145484. [CrossRef] [PubMed]

51. Kucharska, A.; Rushworth, L.K.; Staples, C.; Morrice, N.A.; Keyse, S.M. Regulation of the inducible nuclear dual-specificity phosphatase DUSP5 by ERK MAPK. Cell. Signal. 2009, 21, 1794-1805. [CrossRef]

52. Seo, H.; Cho, Y.C.; Ju, A.; Lee, S.; Park, B.C.; Park, S.G.; Kim, J.H.; Kim, K.; Cho, S. Dual-specificity phosphatase 5 acts as an anti-inflammatory regulator by inhibiting the ERK and NF-kappaB signaling pathways. Sci. Rep. 2017, 7, 17348. [CrossRef]

53. Habibian, J.S.; Jefic, M.; Bagchi, R.A.; Lane, R.H.; McKnight, R.A.; McKinsey, T.A.; Morrison, R.F.; Ferguson, B.S. DUSP5 functions as a feedback regulator of TNF $\alpha$-induced ERK1/2 dephosphorylation and inflammatory gene expression in adipocytes. Sci. Rep. 2017, 7, 12879. [CrossRef] [PubMed]

54. Fujita, K.; Kubota, Y.; Ishida, H.; Sasaki, Y. Irinotecan, a key chemotherapeutic drug for metastatic colorectal cancer. World J. Gastroenterol. 2015, 21, 12234-12248. [CrossRef] [PubMed]

55. Bleiberg, H.; Cvitkovic, E. Characterisation and clinical management of CPT-11 (irinotecan)-induced adverse events: The European perspective. Eur. J. Cancer 1996, 32, S18-S23. [CrossRef] 
56. Ouyang, M.; Luo, Z.; Zhang, W.; Zhu, D.; Lu, Y.; Wu, J.; Yao, X. Protective effect of curcumin against irinotecan-induced intestinal mucosal injury via attenuation of NFkappaB activation, oxidative stress and endoplasmic reticulum stress. Int. J. Oncol. 2019, 54, 1376-1386. [PubMed]

57. Weingart, J.D.; Thompson, R.C.; Tyler, B.; Colvin, O.M.; Brem, H. Local delivery of the topoisomerase I inhibitor camptothecin sodium prolongs survival in the rat intracranial 9L gliosarcoma model. Int. J. Cancer 1995, 62, 605-609. [CrossRef] [PubMed] 